\title{
Comparison of chemical and microbiological methods in the estimation of methionine in cowpea (Vigna unguiculata) seeds
}

\author{
By I. MARTA EVANS \\ Department of Botany, University of Durham, Durham \\ AND J. E. FORD \\ National Institute for Research in Dairying, \\ Shinfield, Reading RG2 $9 A T$ \\ AND L. C. HANNAH \\ Vegetable Crops Department, University of Florida, \\ Gainesville, Florida, USA \\ AND D. BOULTER \\ Department of Botany, University of Durham, Durham \\ (Received 2 March 1976 - Accepted 26 March 1976)
}

\begin{abstract}
I. Meals were prepared from the seeds of fifteen varieties of cowpea (Vigna unguiculata), one of lima bean (Phaseolus lunatus) and one of yam bean (Sphenostylis stenocarpa), and their methionine content was determined by six different methods.

2. Total methionine content was determined by two chemical methods (ion-exchange chromatography and a colorimetric procedure) and by two microbiological methods. The 'available' methionine content was determined by microbiological assay with Streptococcus zymogenes.

3. All the different methods for total methionine determination gave similar results, with much the same high extent of precision.

4. The values for 'available' methionine content were similar to or marginally higher than the corresponding microbiological assay values for total methionine content. There was no indication that the methionine in any of the test samples was not completely available.
\end{abstract}

The nutritional quality of the cowpea (Vigna unguiculata) is determined by its content of sulphur-containing amino acids. We were interested to determine whether different lines of this legume differ significantly in their content of methionine and cystine. If they do, then by the selective use of high-methionine cultivars in breeding it might be possible to establish varieties of improved nutritional quality. Such a programme of breeding for increased methionine content would involve precise and accurate determination of methionine in large numbers of test samples. The present paper reports a preliminary comparative study of methods of methionine determination.

Amino acids in food proteins may suffer nutritional damage during heat-processing or storage; the digestibility of the protein and the biological availability of the constituent amino acids may be reduced, although the amino acid composition as determined by chromatographic analysis of an acid-hydrolysate of the protein may 
indicate little change. Peptide-bound methionine may undergo oxidation in situ, and it has been suggested that these oxidized residues are of low biological availability, being slow to digest in vivo (Ellinger \& Palmer, 1969). In the present study, methionine in all the test proteins was determined by ion-exchange chromatography. This involves hydrolysis with $6 \mathrm{M}-\mathrm{HCl}$, which largely reduces any methionine sulphoxide to the parent amino acid ( $\mathrm{Njaa}$, 1962). As a check on the possible presence of methionine sulphoxide, several of the test samples were also analysed by the colorimetric method of Gehrke \& Neuner (1974), which does not involve hydrolysis with $6 \mathrm{M}-\mathrm{HCl}$ and so might be expected to give a better measure of the amount of methionine actually present. Total methionine was also assayed microbiologically using two different test micro-organisms, Pediococcus cerevisiae and Streptococcus zymogenes, after hydrolysis of the test samples with acid. At the same time, further assays with $P$. cerevisiae were carried out in which the test samples were hydrolysed enzymically with pronase (a proteinase obtained from Streptomyces species) instead of with acid.

As a check on all these different measures of total methionine, the biologically available methionine was assessed using the Strep. zymogenes assay procedure, which has been found to give results that agree fairly closely with those from chick and rat growth assays (Boyne, Ford, Hewitt \& Shrimpton, I975).

The test samples comprised fifteen varieties of cowpea, one of lima bean (Phaseolus lunatus) and one of yam bean (Sphenostylis stenocarpa). In each instance, subsamples for the different analyses were taken from the same batch of material. Some of the test samples were in short supply, and so it was not possible to carry out all six different assay procedures.

\section{EXPERIMENTAL}

\section{Test materials}

Seeds were obtained from the International Institute of Tropical Agriculture, Ibadan, Nigeria, and meals were prepared from them by milling (Model Aro mill; Hanke \& Kunkel KG, Staufen, W. Germany) to pass a 4o-mesh sieve. Samples of the meals were then distributed to the three laboratories taking part in the analyses.

\section{Total nitrogen determinations}

Total $\mathrm{N}$ determinations were carried out by a micro-Kjeldahl technique and the digests were analysed automatically using a Carlo Erba apparatus, as described by Evans \& Boulter (1974a).

\section{Methionine determinations}

I. Ion-exchange chromatography. Meals were hydrolysed in a sealed, evacuated tube $\left(6.67 \mathrm{~N} / \mathrm{m}^{2}\right)$ in $6 \mathrm{M}-\mathrm{HCl}$ at $105^{\circ}$ for $22 \mathrm{~h}$ and then analysed using an autoanalyser (The Locarte Co., Wendell Road, London Wi2 $9 \mathrm{RT}$ ). The details of the method have been described by Evans \& Boulter (1974a).

2. Colorimetric method. Methionine content was determined in enzymic hydrolysates of meals according to the method of Gehrke \& Neuner (1974). A $900 \mathrm{mg}$ portion of cowpea meal was used for each digestion with papain $(E C 3.4 .4 .10)$, and the 
Table I. Total nitrogen ( $\mathrm{g} / \mathrm{kg}$ meal (dry wt basis)) and methionine ( $\mathrm{g} / \mathrm{kg}$ crude protein $(N \times 6 \cdot 25))$ contents of meals prepared from seeds of different varieties of legumes, determined by six different methods

\begin{tabular}{|c|c|c|c|c|c|c|c|}
\hline \multirow{3}{*}{$\begin{array}{r}\text { Method* } \ldots \\
\text { Sample }\end{array}$} & \multirow[b]{3}{*}{$\begin{array}{c}\text { Total } \\
\text { N§ }\end{array}$} & \multicolumn{4}{|c|}{ Total } & \multirow{2}{*}{\multicolumn{2}{|c|}{$\begin{array}{l}\text { 'Pronase- } \\
\text { digestible' 'Available' } \\
\text { Microbiological }\end{array}$}} \\
\hline & & \multirow{2}{*}{$\begin{array}{l}\text { Ion- } \\
\text { exchange } \\
\text { chroma- } \\
\text { tography } \\
(34)\end{array}$} & \multirow{2}{*}{$\begin{array}{l}\text { Colori- } \\
\text { metric } \\
(20)\end{array}$} & \multicolumn{2}{|c|}{ Microbiological } & & \\
\hline & & & & $\begin{array}{l}\text { Pediococcus } \\
\text { cerevisiae } \\
\quad\left(3^{6}\right)\end{array}$ & $\begin{array}{l}\text { Strep. } \\
\text { zymogenes } \\
(24)\end{array}$ & $\begin{array}{l}P . \\
\text { cerevisiae } \\
\quad(44)\end{array}$ & $\begin{array}{l}\text { Strep. } \\
\text { zymogenes } \\
(32)\end{array}$ \\
\hline \multicolumn{8}{|c|}{ Cowpea (Vigna unguiculata): } \\
\hline IVu I 354 & $3^{8 \cdot 8}$ & $19 \cdot 7$ & $17 \cdot 8$ & nd & nd & nd & nd \\
\hline IVu 176 & $44^{\circ} 9$ & II 8 & 10.8 & $12 \cdot 0$ & $12 \cdot 2$ & $12 \cdot 6$ & $14 \cdot 3$ \\
\hline IVu 57 & $51 \cdot 7$ & $12 \cdot 4$ & nd & $10 \cdot 1$ & II 4 & II $\mathbf{2}$ & II 5 \\
\hline IVu $53 \circ$ & $36 \cdot 7$ & $\mathrm{I} 4 \cdot 8$ & nd & $16 \cdot 1$ & $14 \% 7$ & I $5 \cdot 9$ & I5. I \\
\hline IVu I423 & $43 \cdot 3$ & I9:7 & $19 \cdot 2$ & nd & nd & nd & nd \\
\hline IVu 95 & $42 \cdot 3$ & $13 \cdot 6$ & nd & $12 \cdot 1$ & 13.7 & $13 \cdot 8$ & $14 \cdot 5$ \\
\hline 'Prima' (cooked) & $42 \cdot 7$ & I $4 \cdot 3$ & nd & nd & $14 \cdot 1$ & nd & $14 \cdot 5$ \\
\hline 'Prima' (raw) & $4 I \cdot 7$ & $14 \cdot 2$ & 12.9 & $13 \cdot 2$ & $15 \cdot 1$ & 14.0 & I $7 \cdot 1$ \\
\hline IVu 30 & $40 \cdot 7$ & $15 \cdot 6$ & nd & $13 \cdot 1$ & nd & $13 \cdot 4$ & $16 \cdot 4$ \\
\hline IVu 37 & $45^{\circ} \circ$ & I $2 \cdot 3$ & 14.7 & I I 9 & nd & $12 \cdot 0$ & $\mathrm{I}_{4} \cdot \mathrm{O}$ \\
\hline IVu 91 & $4 I \cdot 3$ & 14.3 & nd & $15 \cdot 7$ & nd & $\mathrm{r}_{4} \cdot 2$ & $16 \cdot 0$ \\
\hline IVu 2093 & $40 \cdot 6$ & 13.5 & nd & I $4 \cdot I$ & nd & 14.9 & $16 \cdot 4$ \\
\hline IVu 3629 & $45 \cdot 1$ & 14.0 & 15.5 & $12 \cdot 4$ & nd & $13 \cdot 6$ & nd \\
\hline IVu $155^{-2}$ & $44 \cdot 7$ & 14.3 & $12 \cdot 7$ & I3.4 & nd & $12 \cdot 2$ & nd \\
\hline IVu 32 & $44^{\circ} 5$ & $14 \cdot 8$ & $16 \cdot 4$ & nd & nd & nd & nd \\
\hline $\begin{array}{l}\text { Lima bean (Phaseolus } \\
\text { lunatus) IPI I } 97\end{array}$ & $4 I \cdot 3$ & $12 \cdot 2$ & nd & nd & 9.5 & nd & $12 \cdot 4$ \\
\hline $\begin{array}{l}\text { Yam bean (Sphenostylis } \\
\text { stenocarpa) Akegbe } \\
\text { Enugu III, brown }\end{array}$ & $35 \cdot 3$ & 13.5 & nd & nd & $12 \cdot 2$ & nd & $12 \cdot 5$ \\
\hline sDt & 一 & 0.94 & $\mathrm{I} \cdot 04$ & $1 \cdot 02$ & $\mathrm{I} \cdot 52$ & $\begin{array}{l}I \cdot 65 \\
(I \cdot 23 \|)\end{array}$ & $\begin{array}{l}0.78 \\
0.78\end{array}$ \\
\hline Coefficient of variation & - & $6 \cdot 5$ & $7 \cdot 0$ & $8 \cdot 0$ & I I 8 & $\begin{array}{l}\text { I } 2 \cdot 4 \\
(9 \cdot 3 \|)\end{array}$ & $5 \cdot 4$ \\
\hline $\begin{array}{l}\text { Smallest differences } \\
\text { that may be resolved } \dagger\end{array}$ & - & $2 \cdot 6$ & $2 \cdot 9$ & $2 \cdot 8$ & $4 \cdot 2$ & $\begin{array}{l}4 \cdot 6 \\
(3 \cdot 4 \|)\end{array}$ & $2 \cdot 2$ \\
\hline
\end{tabular}

nd, Not determined.

* For details, see pp. 290-2.

+ Based on the variation between two to four replicates/sample pooled over total number of samples studied.

$\ddagger$ Between two means of two to four independent assays for each sample. Calculated as I ' $96 \times \sqrt{2} \times$ sD.

$\S$ Values for some varieties of cowpeas from Evans \& Boulter (I974a), and those for lima and yam beans from Evans \& Boulter (1974b).

|| Values calculated excluding cowpea sample no. 2093 for which between-assay variation was large in comparison with other samples.

digests were automatically analysed using Carlo Erba apparatus incorporating a colorimeter (Technicon Instruments Co. Ltd, Basingstoke, Hants.) to accommodate a $50 \mathrm{~mm}$ flow-cell.

3. Microbiological methods. Total and 'available' methionine were measured microbiologically with Strep. zymogenes NCDO 592 by the method of Ford (1962), modified as described by Boyne et al. (1975). Methionine content was also determined using $P$. cerevisiae ATCC $80_{42}$ as described by Hannah, Rhodes \& Evans 
Table 2. Correlation matrix for values obtained for methionine content of meals prepared from seeds of different varieties of legumes, determined by five different methods

\begin{tabular}{lcccc}
\multicolumn{1}{c}{ Method: } & $\begin{array}{c}\text { Ion-exchange } \\
\text { chroma- } \\
\text { tography }\end{array}$ & total & $\begin{array}{c}\text { P.cerevisiae } \\
\text { pronase } \\
\text { digestible }\end{array}$ & $\begin{array}{c}\text { Strep. } \\
z y m o g e n e s, \\
\text { total }\end{array}$ \\
$\begin{array}{l}\text { Pediococcus cerevisiae: } \\
\text { total }\end{array}$ & $0.63^{*}$ & - & - & - \\
pronase digestible & 0.57 & $0.82^{* *}$ & - & - \\
$\begin{array}{l}\text { Streptococcus zymogenes: } \\
\text { total }\end{array}$ & $0.84^{* *}$ & 0.79 & $0.87^{*}$ & - \\
available & $0.65^{*}$ & $0.67^{*}$ & 0.70 & $0.84^{* *}$
\end{tabular}

Statistical significance: * $P \leqslant 0.05, * * P \leqslant 0.01$.

(unpublished results): the test samples were hydrolysed either by treatment with $6 \mathrm{M}-\mathrm{HCl}$, or by digestion with pronase. This latter method of hydrolysis gave a measure of the extent to which the methionine in the 'pronase' digest ('pronasedigestible' methionine) was present as the free amino acid and in small peptides.

\section{RESULTS AND DISCUSSION}

Table I gives the mean values for total $\mathrm{N}$ content, and those for methionine content $(\mathrm{g} / \mathrm{kg}$ crude protein $(\mathrm{N} \times 6 \cdot 25))$ obtained by the six different methods, indicating the between-assay variation found for each method. Results for total methionine obtained by ion-exchange chromatography and those for both total and 'pronase-digestible' methionine obtained by the microbiological methods were not significantly different, and they were all about equally precise. There were not sufficient results to support a similar conclusion concerning agreement between those obtained by the colorimetric and microbiological methods, but those obtained by the two chemical methods (ion-exchange chromatography and colorimetry) were not significantly different.

Table 2 indicates the extent to which results obtained by the different methods were correlated. The differences between the samples in their methionine content were small in relation to the errors inherent in all the analytical methods used, and so high correlation coefficients could not be expected. Nevertheless, the results lend support to our conclusion that the different methods gave much the same results.

Total, 'available' and 'pronase-digestible' methionine values were highly correlated, and there was no indication that the methionine in any of the test samples was not completely available. There was indeed a tendency for 'available' methionine values as measured by the Ford ( 1962$)$ procedure to be higher than the corresponding total methionine values.

It remains to be determined whether there exists any wider variation between cowpeas in their content of methionine, and a much larger selection of samples must be studied. Our present results do not indicate any statistically significant 
difference in the results obtained by the different assay methods with respect to the accuracy and sensitivity with which these methods discriminate between the samples.

The authors are grateful to $\mathrm{Mr} \mathrm{K}$. J. Scott for carrying out the microbiological assays with Streptococcus zymogenes, to Dr M. Visvalingam and Dr Ian S. Evans for their help in the statistical analysis of the results, and to Dr K. Rachie of Centro Internacional de Agricultura Tropical, Cali, Columbia, for the supply of samples. I.M.E. and D.B. thank the Ministry of Overseas Development for the financial support. L.C.H. thanks J. Ferrero for his excellent technical assistance and the Rockefeller Foundation for financial support.

\section{REFERENCES}

Boyne, A. W., Ford, J. E., Hewitt, D. \& Shrimpton, D. H. (r975). Br. F. Nutr. 34, I 53. Ellinger, G. M. \& Palmer, R. (1969). Proc. Nutr. Soc. 28, 42A.

Evans, I. M. \& Boulter, D. (1974a). F. Sci. Fd Agric. 25, 3 I I.

Evans, I. M. \& Boulter, D. (1974b). F. Sci. Fd Agric. 25, 919.

Ford, J. E. (1962). Br. Ұ. Nutr. 16, 409.

Gehrke, C. W. \& Neuner, T. E. (1974). F. Ass. off. Analyt. Chem. 57, 682.

Njaa, L. R. (1962). Acta chem. scand. 16, I359. 